\title{
Swarming modulatory effects of some amino acids on Proteus strains from Lagos, Nigeria
}

\author{
Bamidele A. Iwalokun* and Babatunde O. Akinwumi \\ Biochemistry Department, Lagos State University. P.M.B. 1087. Apapa - Lagos, Nigeria \\ Accepted 9 September 2002
}

\begin{abstract}
Swarming motility, a multicellular behaviour characterized by periodic concentric growth on solid media has severally been reported as a constraint in the clinical investigation of mixedculture infections involving Proteus and as a requirement for virulence. While media are being formulated to restrain swarming in this organism, the roles played by amino acids in the biogenesis of swarming have not been fully clarified. The effects of 20 amino acids on swarming, extracellular protease activity, cellular RNA level and total protein concentration in 20 clinical Proteus strains from Lagos, Nigeria were investigated. At $0.5 \mathrm{mM}$ concentration, glutamine, serine, and methionine were the only amino acids found to enhance swarming motility on M9 minimal medium (7.1-11.3 $\mathrm{mm})$, cause significant increases in protease activity (33.7-48.3 units $/ \mathrm{ml})$, total protein concentration $(22.5-28.6 \mathrm{mg} / \mathrm{ml})$ and cellular RNA concentration $(192.8-264.7 \mu \mathrm{g} / \mathrm{ml})$ when compared to values obtained for other 17 amino acids $(P<0.05)$. Furthermore, the amino acid induced swarming in these strains was found to vary directly and significantly $(P<0.05)$ with protease activity and cellular RNA concentration. The exclusion of methionine, serine and glutamine when supplementing antiswarming media for clinical investigation of Proteus - associated polymicrobial infections in Nigeria is suggested.
\end{abstract}

Key words: Proteus strains, swarming motility, amino acids, Lagos.

\section{INTRODUCTION}

Many recurrent cases of bacteruria and urinary tract infections involving Proteus have been reported (Lopatkin et al., 2001; Pfau and Sacks, 1992). The reoccurrence of these diseases have been attributed to polymicrobial etiology through cultures, which is sometimes undetected (van Asten and Gaastra, 1999). Proteus exhibits swarming motility, a growth behavior that may overwhelm the growth of other pathogens

\footnotetext{
* Corresponding author; e-mail: bamwal@yahoo.com; tel: 234-12601089
}

thereby annulling plans for an adequate antibiotic regimen options. Proteus swarming behavior could be refrained on minimal media supplemented with substances such as urea, activated charcoal, sodium azide, nitrophenylglycerol and alcohol (William, 1973; Hernandez and Cavallo, 1999). However, the effects of these substances on other pathogens remain largely unknown. Although minimal media are supportive to the growth of Proteus and Pseudomonas species (Dick et al., 1985), it is grossly inadequate to meet the growth requirements of fastidious pathogenic microorganisms (Marshall et al., 1984; Reynolds and Penn, 1994). In this regard media fortification with amino acids that will promote growth of pathogens but inhibit swarming is highly desirable.

Studies on swarming enhancing effects of amino acids 
in Nigeria are scarce but available data from studies conducted elsewhere, revealed variability in the ability of polar and non-polar amino acids to support swarming motility in Proteus species (Ulitzer, 1975; Eberl et al., 1999). Swarming motility has also been linked to virulence in Proteus. Allison et al. (1992a) showed the dependence of Proteus mirabilis invasion of urothelial cells on motility and swarming differentiation. In the present study, the swarming modulatory effects of 20 amino acids were investigated. In order to provide biochemical evidence for this behavior in relation to virulence, cellular RNA, extra-cellular protease activity and level of total protein in 20 Proteus strains were also determined.

\section{MATERIALS AND METHODS}

\section{Proteus strains}

Twenty clinical Proteus strains that displayed swarming motility on nutrient and blood agar media were recruited for study. They were recovered from agar slants in the Genetic and Biotechnology Department of the Nigerian Institute of Medical Research. Yaba - Lagos. Before use, the strains were subjected to biochemical characterization for clarification (Cowan, 1974).

\section{Effects of amino acids on Swarming motility}

$20 \mu \mathrm{l}$ of an overnight culture of Proteus in LB broth was subcultured in a test tube containing $10 \mathrm{ml}$ of $\mathrm{M} 9$ minimal media $\left(\mathrm{Na}_{2} \mathrm{HPO}_{4}, 1.28 \% ; \mathrm{KH}_{2} \mathrm{PO}_{4}, 0.31 \% ; \mathrm{NH}_{4} \mathrm{Cl}, 0.1 \%\right.$; Glucose, $0.4 \%$ ) supplemented with $0.5 \mathrm{mM}$ of each of the 20 amino acids tested. They were glutamine (GIn), glutamate (Glu), aspartate (Asp), asparagines (Asn), tryptophan (Trp), tyrosine (Tyr), Phenylalanine (Phe), glycine (Gly), cysteine (Cys), proline (Pro), leucine (Leu), valine (Val), methionine (Met), lysine (Lys), threonine (Thr), alanine (Ala), isoleucine (lleu), histidine (His), arginine (Arg), serine (Ser). The inoculated tubes were incubated aerobically at $37^{\circ} \mathrm{C}$ for 24 hours. Meanwhile, at $8 \mathrm{~h}$ incubation, $3 \mu \mathrm{l}$ of culture was used to inoculate another batch M9 minimal media but solidified with $0.6 \%$ Eiken agar at the center. At $24 \mathrm{~h}$, the outer diameter of swarming zone from the point of inoculation was measured in millimeter. Broth cultures were also centrifuged (3000 rpm, 10 minutes, $\left.0^{\circ} \mathrm{C}\right)$, cell pellets were lysed and lysate was used for RNA estimation. Total protein and protease activity were measured using the cell fee supernatant.

\section{Total Cellular RNA Estimation}

The total cellular RNA was determined following the reaction of cell lysate with orcinol reagent as described by Jayaraman (1988). Initially, the bacterial cells obtained as pellets of M9 minimal media culture were dispersed in $200 \mu \mathrm{l}$ of $0.1 \mathrm{M}$ Tris-EDTA buffer ( $\mathrm{pH} 8.0)$ and then lysed by adding $400 \mu$ lysing solution (3\% SDS in $50 \mathrm{mM}$ Tris- $\mathrm{HCl}$ and $2 \mathrm{~N} \mathrm{NaOH}$ ) for $5 \mathrm{~min}$. Cell lysis was stopped by the addition of $300 \mu$ l sodium acetate buffer ( $\mathrm{pH}$ 5.5). The suspension was subsequently centrifuged (5000rpm) for $5 \mathrm{~min}$ at $4^{\circ} \mathrm{C}$. The supernatant obtained was used for total RNA estimation.

\section{Cell-Free Protein Determination}

The method of Lowry et al. (1951) was adopted to determine the concentration of total protein secreted by the Proteus strains tested under the influence of amino acids. Bovine serum albumin $(500-1250 \mu \mathrm{g} / \mathrm{ml})$ was employed as standard protein.

\section{Extracellular Protease Activity}

Protease activity was measured as described by $\mathrm{Li}$ and Yousten (1975) with some modifications. Overnight culture of Proteus in M9 minimal media was centrifuged (3000 rpm, $10 \mathrm{~min}, 0^{\circ} \mathrm{C}$ ) and the resulting supernatant was filter-sterilized by passage through a $45 \mu \mathrm{M}$ Millipore filter. $50 \mu \mathrm{l}$ of the cell free filtrate was pipetted in a tube containing $1 \mathrm{ml}$ of $0.5 \%$ bovine serum albumin (BSA) and $2 \mathrm{ml}$ of phosphate-saline buffer (PBS, $\mathrm{pH}$ 7.2). After mixing, the assay mixture was incubated at $37^{\circ} \mathrm{C}$ for 1 hour. Digestion was terminated by adding 0.5 $\mathrm{ml}$ of $5 \%$ trichloroacetic acid (TCA). One unit of protease activity was defined as the amount of enzyme that caused a 0.01 increase in absorbance at $280 \mathrm{~nm}$ under the assay conditions.

\section{Statistical analysis}

Data were expressed as range and mean \pm standard 
Table 1. Swarming motility and biochemical changes in Proteus strains grown in M9 minimal media supplemented with amino acids.

\begin{tabular}{|c|c|c|c|c|}
\hline Amino acids & Protease (unit/ml) & Total Protein $(\mathrm{mg} / \mathrm{ml})$ & RNA $(\mu \mathrm{g} / \mathrm{ml})$ & $\mathrm{OCZD}(\mathrm{mm})$ \\
\hline Glu & 14.2 & 11.2 & 138.0 & 2.0 \\
\hline Cys & 14.5 & 10.3 & 132.0 & 2.0 \\
\hline *Met & 38.3 & 26.1 & 224.8 & 7.3 \\
\hline Asp & 14.3 & 10.3 & 135.4 & 1.0 \\
\hline Asn & 12.8 & 9.4 & 134.0 & 1.0 \\
\hline${ }^{*} \mathrm{Gln}$ & 48.3 & 28.6 & 264.7 & 11.2 \\
\hline $\operatorname{Trp}$ & 15.6 & 11.1 & 139.2 & 2.0 \\
\hline Tyr & 15.6 & 10.3 & 128.5 & 1.0 \\
\hline Phe & 18.3 & 12.2 & 142.5 & 1.0 \\
\hline Gly & 21.5 & 12.9 & 166.2 & 1.5 \\
\hline *Ser & 33.7 & 22.5 & 192.8 & 7.1 \\
\hline Leu & 16.3 & 11.7 & 140.7 & 1.8 \\
\hline Val & 12.8 & 9.8 & 135.0 & 1.9 \\
\hline Pro & 14.7 & 10.6 & 134.0 & 1.7 \\
\hline Lys & 18.6 & 12.2 & 148.4 & 2.2 \\
\hline Thr & 18.0 & 12.1 & 153.5 & 2.4 \\
\hline Ala & 12.2 & 9.4 & 149.0 & 1.0 \\
\hline Ileu & 19.6 & 13.5 & 158.6 & 2.4 \\
\hline Arg & 20.4 & 12.8 & 161.4 & 1.6 \\
\hline His & 23.8 & 14.2 & 163.8 & 1.5 \\
\hline
\end{tabular}

deviation. Differences between mean values were compared for significance using the student's $t$ - test. Relationships between parameters were assessed by regression analysis. $\mathrm{P}$ value $<0.05$ was considered significant in all cases.

\section{RESULTS}

Table 1 summarized the effects of the twenty amino acids at $0.5 \mathrm{mM}$ on extracellular protease activity, swarming motility, total protein concentration and 
cellular RNA level in 20 Proteus strains grown in M9 minimal medium. Higher cellular RNA level was observed in media supplemented with glutamine $(264.7$ $\mu \mathrm{g} / \mathrm{ml})$, methionine $(224.8 \mu \mathrm{g} / \mathrm{ml})$ and serine (192.8 $\mu \mathrm{g} / \mathrm{ml}$ ) when compared with levels observed with respect to the remaining 17 amino acids $(132-166.2 \mu \mathrm{g} / \mathrm{ml})$.
Similarly, higher concentration of total protein (22.5-28.6 $\mathrm{mg} / \mathrm{ml}$ ) and extracellular protease activity (33.7-48.3 units $/ \mathrm{ml}$ ) in glutamine, methionine and serine media compared with those supplemented with the remaining 17 amino acids (protease: $12.2-23.8$ units $/ \mathrm{ml}$; protein: $9.4-14.2 \mathrm{mg} / \mathrm{ml}$ ). Unlike in the glutamine, methionine,

Table 2. Comparative evaluation of biochemical parameters in M9 minimal media based on amino acid supplementation.

\begin{tabular}{|c|c|c|c|c|}
\hline Parameters & $\mathbf{a}$ & b & $\mathrm{t}$ & $P$ \\
\hline Protein $(\mathrm{mg} / \mathrm{ml})$ & $25.7 \pm 3.1$ & $11.7 \pm 1.4$ & 12.02 & $<0.05$ \\
\hline Cellular RNA $(\mu \mathrm{g} / \mathrm{ml})$ & $227.4 \pm 36.0$ & $144.7 \pm 12.7$ & 7.03 & $<0.05$ \\
\hline Protease (units/ml) & $40.1 \pm 7.5$ & $16.7 \pm 3.3$ & 8.44 & $<0.05$ \\
\hline \multicolumn{5}{|c|}{$\begin{aligned} & \mathbf{a}= \text { Parameters measured in Proteus strains grown in minimal media } \\
& \text { supplemented with glutamine, methionine and serine. } \\
& \mathbf{b}= \text { Parameters measured in Proteus strains grown in minimal media } \\
& \text { supplemented with the remaining } 17 \text { amino acids. } t=\text { student's } t-\text { test. } \\
& P<0.05 ; \text { mean values in } \mathbf{a} \text { is significantly greater than those in } \mathbf{b} \text { at } 95 \% \\
& \text { confidence level }\end{aligned}$} \\
\hline
\end{tabular}

Table 3. Variation in glutamine, methionine and serine induced increases in cellular RNA, total protein and protease activity among the Proteus strains.

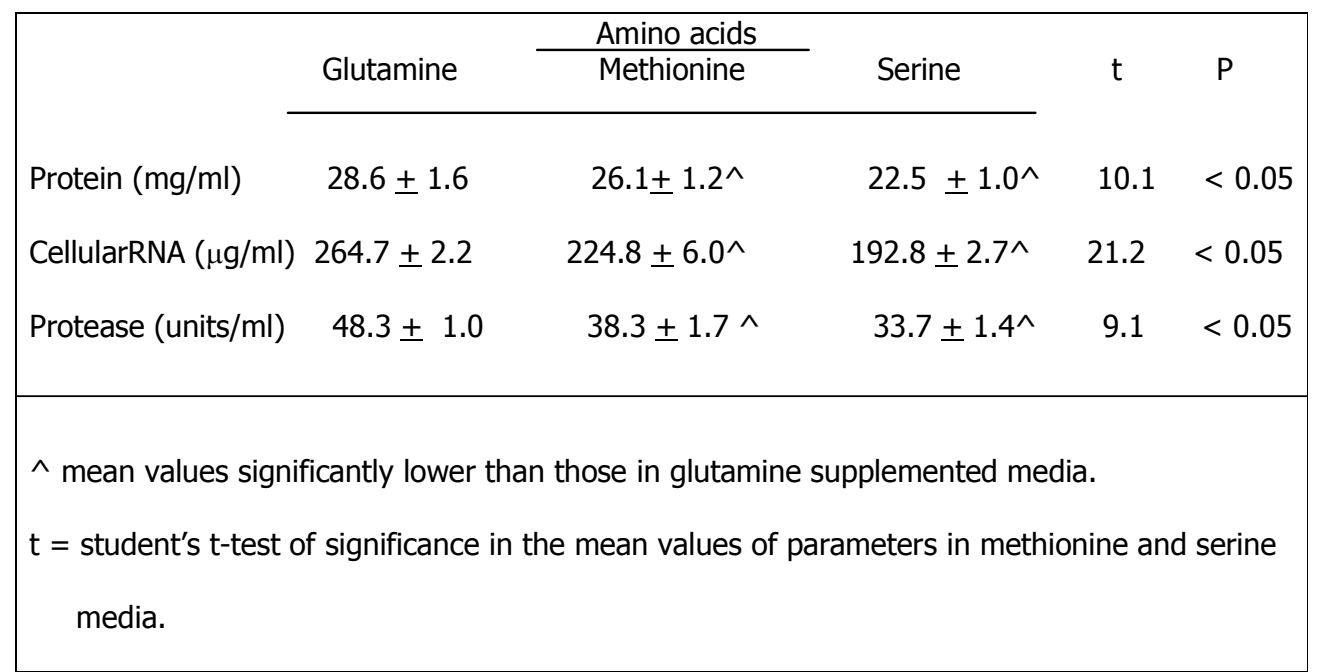


and serine supplemented media where outermost colony zone diameter (OCZD) range of $7.1-11.2 \mathrm{~mm}$ was observed, 13 of the remaining 17 amino acids resulted in OCZD $\leq 2 \mathrm{~mm}$ after $24 \mathrm{~h}$ of growth of the Proteus strains.

The observed increases of these biochemical parameters in the glutamine, methionine, and serine minimal media were further found to be significant $(t=$ 8.44-12.02; $P<0.05$ ) (Table 2). Further comparison of these biochemical parameters between glutamine supplemented media and those fortified with methionine and serine indicated greater and significant $(P<0.05)$ enhancing effects of glutamine on protease activity (48.3 vs 33.7 and 38.2 units $/ \mathrm{ml}$ ), total protein concentration (28.6 vs. 22.5 and $26.1 \mathrm{mg} / \mathrm{ml}$ ) and cellular RNA level $(264.7$ vs 192.8 and $224.8 \mu \mathrm{g} / \mathrm{ml})$. Methionine supplementation subsequently produced significant elevation in these biochemical parameters compared with the effect of serine $(\mathrm{t}=9.1-21.2 ; \mathrm{P}<0.05)$ (Table 3).

Linear and significant relationships were also observed between swarming motility and protease activity ( $r$ $=0.49, P<0.05$ ) and between swarming motility and cellular RNA levels $(r=0.47 ; P<0.05)$ among the Proteus strains grown in serine, glutamine and methionine M9 minimal media (Figure 1).

\section{DISCUSSION}

The survival and growth of the Proteus strains tested in M9 minimal media further demonstrates the ability of this organism to biosynthesize growth factors from simple nitrogen, carbon and energy substances. However, the inability of M9 medium to support swarming is in contrast to the growth studies in Luria-Bertani medium in which swarmed Proteus cells expressing fimbrae and pilli were cultured (Latta et al., 1999). Thus, M9 minimal media is ideal for investigating the physiological roles of substances in swarming motility of Proteus in vitro.

The observed enhancement of swarming by glutamine, serine and threonine following supplementation is indicative of a strong contribution of these amino acids to swarm cell differentiation in these strains. Glutamine has previously been described as swarming enhancing agent in Serrrattia liquefaciens, Aeromonas species (Kirov et al., 1986), Vibrionaceae (McCarter and Silverman, 1990) and Proteus spp from other environments (Allison et al., 1993). The compliance of our result to this finding has further validated the universality of glutamine for this function.
Still lacking a define mechanism of action, studies have strongly implicated glutamine as a chemoattractant and a positive signal for co-ordinate expression of genes involved in swarming motility. Most of these genes

A
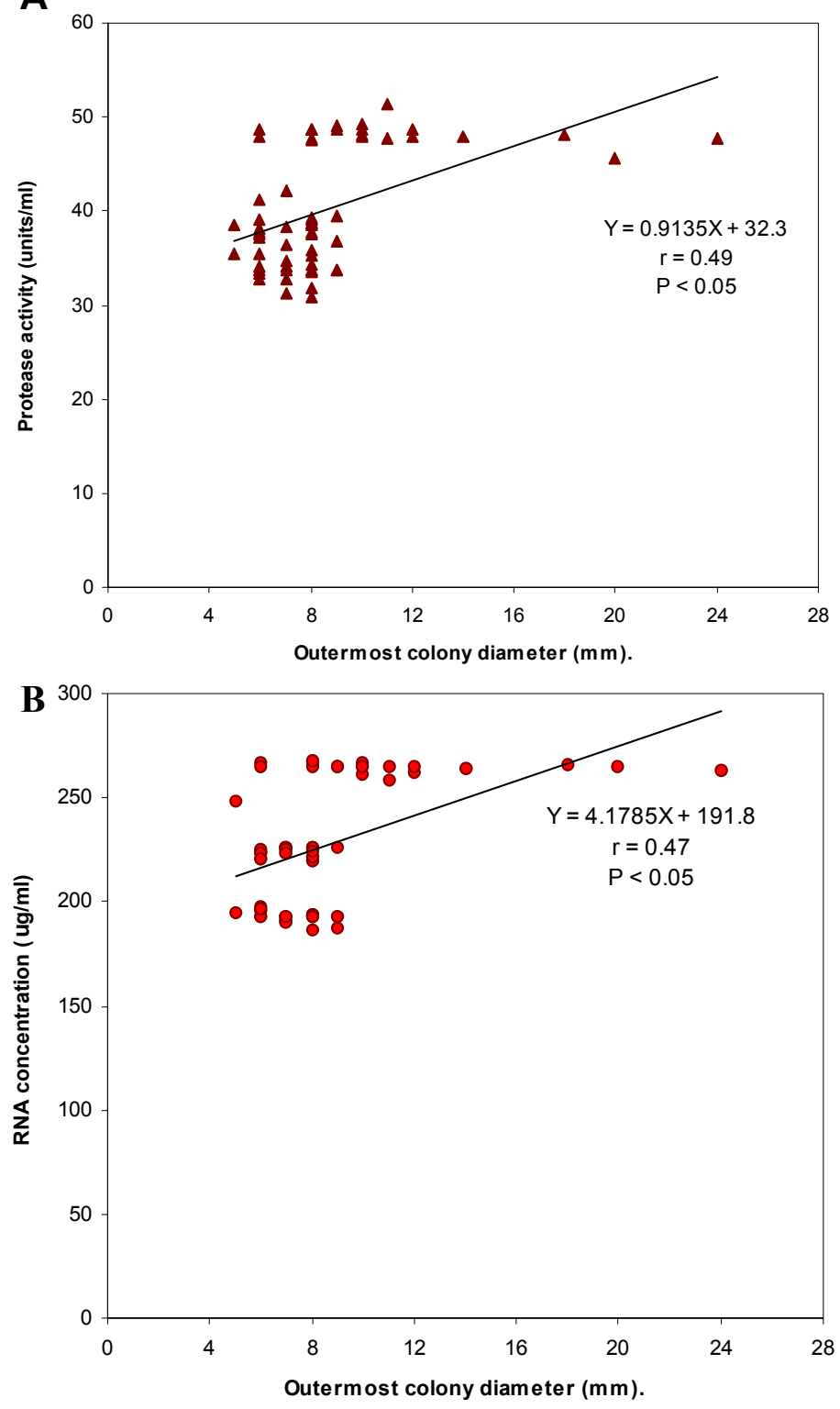

Figure 1. Swarming modulatory effects of serine, glutamine and methionine in Proteus. Proteus strains were grown in M9 minimal media supplemented with serine, glutamine and methionine. (A) Relationship between swarming motility and extracellular protease activity. (B) Relationship between swarming motility and cellular RNA level. 
exhibit a high degree of homology in these organisms (Allison et al., 1991). The capsular polysaccharides of Proteus mirabilis, a requirement for swarming motility in this organism (Beynon et al., 1992) have been analyzed to contain branching amino sugars: glucosamine and galactosamine, which are formed via amino group transfer process. Glutamine might serve as a universal amino group donor in this reaction. The involvement of glutamate could be ruled out since the amino acid was not observed to enhance swarming in this study. Amino acids such as glycine, asparagines, aspartate, lysine, histidine also produced relatively lower protease activity, protein and RNA level in direct relationship with outer colony zone diameter suggesting their inability to cause marked swarming motility in these strains.

However, the ability of methionine to support swarming in our strains is a further reflection of the indispensable requirement of this amino acid in swarming differentiation in these organisms. Eberl et al. (1999) pointed out that an amino acid found indispensable for swarming is highly essential in biosynthesis and operation of the hundreds of flagella produced during swarming differentiation. In addition to flagella master control system, cell-to-cell signaling has also been extensively demonstrated to regulate biosynthetic pathways involved in signal molecules production and swarm cell differentiation in organisms that display swarming motility (Eberl et al., 1996a; Glessner et al., 1998). These signal molecules include serrewatins and acylhomoserine lactones (AHLs). Methionine could be a precursor of the latter and this is subject to further investigation.

In a few studies, branched chain amino acids including isoleucine and valine were found to promote swarming motility in Escherichia coli strain growing on minimal media (Tao et al., 1999). This strain-dependent requirement for swarming-enhancing amino acids may explain the result obtained for serine in this study.

That other amino acids could not support swarming motility in the strains investigated might be due to concentration tested and the genetic disposition of these organisms. All the strains displayed growth in all the supplemented M9 minimal media, indicating a growth promoting function of these amino acids.

Significant activities of extracellular protease and high concentrations of protein and cellular RNA were also exhibited by the glutamine, serine and methionine induced swarmed cells. This observation is in support of the findings of Liaw et al. (2000) in which pnitrophenylglycerol an anti-swarming agent was found to inhibit swarming and expression of virulence factors including Protease in Proteus mirabilis. Eberl et al. (1996b) also demonstrated high levels of gene expression in Serratia liquefaciens during hyperflagellation and swarm cell differentiation. While Allison et al. (1992b) showed that the uropathogenicity of pathogenic Proteus is coupled to swarming behavior. The observed high level of protein could be a reflection of virulence and swarming agents present in the culture media. Those that have been implicated and which are proteins include urease, haemolysins, protease, flagellin, fimbrae and pilli.

The variation in the expression of proteins and cellular RNA level in glutamine, methionine and serine swarmed cells is an indication that these amino acids have different modes of swarming promoting action. Finally, based on the swarming enhancing potentials of serine, glutamine and methionine, we suggest the exclusion of these amino acids when supplementing media for the diagnosis of polymicrobial infections involving Proteus strains from Lagos, Nigeria. However, further studies are required to elucidate the molecular basis of amino acid Proteus interaction that leads to support or negation of swarming motility in this organism.

\section{REFERENCES}

Allison C, Coleman N, Jones PL, Hughes C (1992a). Ability of Proteus mirabilis to invade human urothelia cells is coupled to motility and swarming differentiation. Infect. Immun. 60:4740-4746.

Allison C, Hughes C (1991). Closely linked genetic loci required for swarm cell differentiation and multicellular migration of Proteus mirabilis. Mol. Microbiol. 5:1975-1982.

Allison C, Lai HC, Hughes C (1992b). Co-ordinate expression of virulence genes during swarm-cell differentiation and population migration of Proteus mirabilis. Mol. Microbiol. 6:1583-1591.

Allison CHC, Lai DG, Huches C (1993). Cell differentiation of Proteus mirabilis is initiated by glutamine, a specific chemoattractant for swarming cells. Mol. Microbiol. 8: 53-60.

Beynon LM, Dumanski AJ, McLean RJ, MacClean LL, Richards JC, Perry MB (1992). Capsule structure of Proteus mirabilis (ATCC 49565). J. Bacteriol. 174:2172-2177.

Cowan, ST (1974). Manual for identification of medical bacteria. 2nd ed. London: Cambridge University Press.

Dick H, Murray RG, Walmsley S (1985). Swarmer cell differentiation of Proteus mirabilis in fluid media. Can. J. Microbiol. 31:1041-1050.

Eberl L, Christiansen G, Molin S, Givskov M (1996b). Differentiation of Serratia liquifaciens into swarm cells is controlled by the expression of the flhD mastrer operon. J. Bacteriol. 178:554-559.

Eberl L, Molin S, Givskov M (1999). Surface motility of Serratia liquefaciens MGI. J. Bacteriol. 181:1703-1712.

Eberl L, Winson MK, Sternberg C, Stewart GSAB, Christiansen G, Chhabra SR, Daykin M, Williams P, Molin S, Givskov S (1996a). Involvement of $\mathrm{N}$-acyl-L-homoserine lactone autoinducers in control of multicellular behavior of Serratia liqufaciens. Mol. Microbiol. 20:127-136.

Glessner A, Iglewski BH, Robinson JB (1998). The role Pseudomonas aeruginosa las and rhl quorum sensing systems in control of twitching motility. In Abstracts of the 98th General Meeting of the American Society for Microbiology. Washington, DC p. 227. 
Hernadez E, Ramisse F, Cavallo JD (1999). Abolition of Swarming of Proteus. J. Clin. Microbiol. 37:3435-3435.

Jayaraman J (1988). RNA estimation. In: Jayaraman, J (ed). Laboratory manual in biochemistry. 3rd edition. New Delhi: Wiley Eastern Limited pp. $114-115$.

Kirov SM, Rees B, Wellock RC, Goldsmid JM, VanGalen AD (1986). Virulence characteristics of Aeromonas spp. in relation to source and biotype. J. Clin. Microbiol. 24:827-834.

Latta RK, Grondin A, Jarell HC, Nicholls GR, Berube LR (1999). Differential expression of non-agglutinatiing fimbriae and MR/P pilli in swarming colonies of Proteus mirabilis. J. Bacteriol. 181:32203225.

Li E, Yousten A (1975). Metalloprotease from Bacillus thuringiensis. Appl. Microbiol. 30:354 - 355.

Liaw SJ, Lai HC, Ho SW, Luh KT, Wang WB (2000). Inhibition of virulence factor expression and swarming differentiation in Proteus mirabilis by p-nitrophenylglycerol. J. Med. Microbiol. 49:725-731.

Lopatkin NA, Derevianko H, Nefedova LA, Lavrinova LN, Prudnokova SA (2001). Clinical significance of infection pathogen resistance in a urological clinic for selection of antibacterial therapy regimes for the treatment of complicated urinary infections. Antibiot. Khimioter. 46:21-26.

Lowry OH, Rosebrough NJ, Farr AL, Randall RJ (1951). Protein measurement with the folin phenol reagent. J. Biol. Chem. 193:265-275.
Marshall BJ, Royce H, Annear DI, Godwin CS, Pearman JW, Warren JR, Armstrong JA (1984). Original isolation of Campylobacter pyloridis from human gastricmucosa. Microbios. Lett. 140:26492656.

McCarter L, Silverman M (1990). Surface-induced swarmer cell differentiation of Vibrio parahaemolyticus. Mol. Microbiol. 4:10571062.

Pfau A, Sacks TG (1992). Effective prophylaxis for recurrent urinary tract infections during pregnancy. Clin. Infect. Dis. 14:810-814.

Reynolds DJ, Penn CW (1994). Characteristics of Helicobacter pylori growth in defined medium and determination of its amino acid requirements. Microbiology 140:2649-2656.

Tao H, Bausch C, Richmond C, Blatttner FR, Tyrell C (1999). Functional genomics: Expression analysis of Escherichia coli growing on minimal media. J. Bacteriol. 181:6425-6440.

Ulitzer S (1975). The mechanism of swarming of Vibrio alginolyticus. Arch. Microbiol. 104:67-71.

van Asten FJA, Gaasttra W (1999) Urea restrains swarming of Proteus mirabilis. J. Clin. Microbiol. 37:1652-1652.

William FD (1973). Abolition of swarming of Proteus by $p$ nitrophenylglycerin: application to blood agar. Appl. Microbiol. 25:751-754. 